\author{
P. Campisi, M. G. Dia \& M. L. Marino
}

\title{
An analysis of the bryophyte flora in Sicilian archaeological areas*
}

\begin{abstract}
Campisi, P., Dia, M. G. \& Marino, M. L.: An analysis of the bryophyte flora in Sicilian archaeological areas. - Fl. Medit. 29: 143-157. 2019. — ISSN: 1120-4052 printed, 2240-4538 online.

An analysis of the bryophyte diversity in the studied Sicilian archaeological areas was conducted, highlighting which species are more common and potentially harmful on the ruins.

The floras are much diversified and the presence of some rare taxa highlights the role of refuge carried out by these areas, especially for the species of strongly threatened coastal habitats. Attention on the complexity of the relationships between restoration interventions on lithic structures and conservation needs of the rare and interesting taxa is point out.
\end{abstract}

Key words: Mediterranean area, biodeterioration, rare bryophyte taxa.

\section{Introduction}

Among Italian regions, Sicily is certainly one of those that boasts a particularly rich archaeological heritage, consisting of over 50 sites distributed throughout the territory, in many cases subjected to specific protections (Grella \& al. 1997).

As evidenced by several studies, the archaeological areas are of considerable interest also from the naturalistic point of view as they represent refuge areas for numerous species threatened by urban expansion and generally host a high floristic diversity (Celesti Grapow \& al. 1993-1994; Lucchese \& Pignatti Wikus 1995; Ceschin \& al. 2006; Minissale \& al. 2015).

In Italy the studies on the flora of the archaeological sites started in the Nineties and Sicily is one of the regions most concerned by this research activity (Domina 2018).

In addition to the vascular component, also the cryptogamic one was investigated in Sicily, in order to improve the knowledge of the main biodeteriogens on the remains of the ancient human-made structures (Raimondo \& al. 2008). Several researches have focused in particular on bryophyte floras, starting from the Nineties, as was pointed out by Gueli $\&$ al. (2005). Some of these studies have highlighted the presence in Sicilian archaeological areas of very rare taxa and therefore of conservation interest (Dia \& al. 2003; Campisi

*Extended and enriched version of the oral presentation given at the International Symposium "Botany at the intersection of Nature, Culture, Art and Science", Selinunte, 28-30 June 2018. 
\& Provenzano 2004; Dia \& Campisi 2006;Campisi \& al. 2008; Dia \& Campisi 2009), drawing attention to the need to clarify the deteriogenic role of bryophytes to evaluate in some cases the hypothesis of their maintenance on the ruins.

Here we analyze so far studied bryophyte floras in some archaeological areas of Sicily with the aim of evaluating the bryophyte diversity of the areas and highlighting which species are more common and potentially harmful on the ruins as well as wich species are worthy of conservation.

\section{Materials and methods}

The Archaeological Parks of Solunto and of Mount Iato in Palermo province, those of Segesta and Selinunte e Cave di Cusa in Trapani province, the Neapolis Archaeological Park of Syracuse town, the Temple of Cerere in Enna province and the Greco-Roman Theatre and the Roman Amphitheatre inside Catania town have been taken into consideration in this analysis (Table 1). In view of their naturalistic interest, some of these areas, in particular Mount Iato Archaeological Park, Selinunte and Cave di Cusa Archaeological Park and Solunto Archaeological Park, are included in the list of Sites of Community Interest (ITA020027 Monte Iato, Kumeta, Maganoce e Pizzo Parrino; ITA010011 Sistema dunale Capo Granitola, Porto Palo e Foce del Belice; ITA020019 Rupi di Catalfano e Capo Zafferano).The present study was based on bibliographic and unpublished data. In particular, we have considered the papers of Privitera \& al. (1996), Lo Giudice \& Cristaudo (1998), Di Benedetto \& Grillo (1998), Puglisi (1999), Guglielmo \& al. (2003) and Aiello \& al. (2003). Furthermore, the data concerning bryophyte material collected by the authors in the Sicilian archaeological areas of Selinunte and Mount Iato were also taken into consideration.

The archeological areas of Selinunte, Syracuse, Catania, Solunto and Segesta are located at lowland or hilly altitudes (10-415 m a.s.1.) on the contrary Mount Iato and Enna are located at sub-mountain altitudes (850-970 $\mathrm{m}$ a.s.1.). Vegetation is mostly represented by xerophilous or mesophilous grasslands and garrigues; only at Selinunte psammophilous, wetlands communities and Mediterranean maquis also occur (Table 1).

The relevant samples are kept at the Herbarium Mediterraneum Panormitanum (PAL).

Table 1. Studied areas and relatives data of surface, altitude and vegetation types.

\begin{tabular}{|l|c|c|c|c|}
\hline \multicolumn{1}{|c|}{ Archaeological area } & Abbreviation & $\begin{array}{c}\text { Altitude } \\
\text { (m a.s.l.) }\end{array}$ & $\begin{array}{c}\text { Area } \\
\text { size } \\
\text { (ha) }\end{array}$ & Vegetation type \\
\hline Mount Iato Archaeological Park (Palermo) & Ia & 850 & 40 & Mesophilous grasslands, garrigues \\
\hline Segesta Archaeological Park (Trapani) & Sg & 415 & 30 & Xerophilous grasslands, garrigues \\
\hline Selinunte and Cave di Cusa Archaeological Park (Trapani) & Sl & 10 & 215 & $\begin{array}{c}\text { Psammophilous communities, } \\
\text { Mediterranean maquis, wetlands } \\
\text { communities, crops }\end{array}$ \\
\hline Neapolis Archaeological Park (Syracuse) & Si & 25 & 22 & Xerophilous grasslands, crops \\
\hline Solunto Archaeological Park (Palermo) & So & 215 & 20 & Xerophilous grasslands, garrigues \\
\hline Greco-Roman Theatre and the Roman Amphitheatre (Catania) & Ca & 25 & 0,6 & Sinantropic communities \\
\hline Temple of Ceres (Enna) & En & 970 & 0.4 & Subnitrofilous xerophilous grasslands \\
\hline
\end{tabular}


The nomenclature of the species comply with Söderström \& al. (2016) for liverworts and hornworts and Ros \& al. (2013) for mosses, with the exception of Didymodon tophaceus complex for which Kučera \& al. (2018) is followed .

In order to characterize the floras of Sicilian archaeological areas, chorological and ecological features were compared. Chorotypes were taken from Düll (1983, 1984, 1985, 1992), where almost all taxa of studied sites are reported, with same abbreviations and for the construction of the chorological histogram they were after joined in five groups: temperate (temp, s.temp, temp-mont, subkont); oceanic-Mediterranean (oc-med, oc-submed, suboc-med, subocsubmed); Mediterranean (med, med-oc, submed, submed-oc, submed-suboc, submed-subocmont submed-mont); boreal (subbor, subbor-mont); oceanic (suboc).

Ellenberg's indicator values relating to light, temperature, moisture and substrate reaction, were taken from Düll (1991).

All available data were assembled in a Microsoft Access database, where for each taxon ecological indicator values, chorotypes, and occurrence in the Sicilian archaeological areas were recorded.

For each site, the ecological indicator mean values were calculated to draw radar diagram. In order to measure the level of similarity of the floras, a hierarchical cluster analysis using Jaccard's similarity index (Jaccard 1908), applied on a data matrix including presence-absence of moss and liverwort taxa, was performed with the Biodiversity Professional program (McAleece \& al. 1997).

The bioclimatic thermotypes were derived from the thermotypes map provided by Pesaresi \& al. (2014).

Moreover, with the aim of identifying the potentially most dangerous species for the integrity of the ruins, in the sites of Selinunte, Segesta and Solunto the following data were recorded by the authors in the field and analized:

1) frequency of taxa in five classes based on percentage occurrence in the total collection points of every archaeological area (I: 0-20\%, II: $21-40 \%$, III: $41-60 \%$, IV: $61-80 \%$, V: $81-$ $100 \%$ ); 2) percentage cover in five classes based on percentage cover of each species on the total surface colonized by the bryophytes in $30 \times 30 \mathrm{~cm}$ areas, in every archaeological area (I: 0-20\%, II: $21-40 \%$, III: 41-60\%, IV: $61-80 \%$, V: $81-100 \%$ ); 3) sporophyte or propagule production (production was considered high $(+)$ when their occurrence was recorded in more than $30 \%$ of plants in the collected specimens, low (-) if in 30\% of plants or less).

Life strategies were taken from Dierßen (2001) with same abbreviations.

In all figures and tabular material studied sites were indicated with following abbreviations: Ca: Greco-Roman Theatre and the Roman Amphitheatre in Catania town; En: Temple of Ceres in Enna town; Ia: Mount Iato Archaeological Park; Sg: Segesta Archeological Park: Si: Neapolis Archaeological Park in Syracuse town; Sl: Selinunte and Cave di Cusa Archeological Park; So: Solunto Archaeological Park.

\section{Results and Discussion}

Overall, the bryophyte flora of the Sicilian archaeological areas studied so far includes 88 taxa (75 mosses and 13 liverworts). They are listed in Table 2, where the presence in each area, ecological indicators and chorotypes are reported. 
Table 2. List of taxa of studied archaeological areas and their ecological indicators (from Düll 1991) and chorotypes (from Düll 1983, 1984, 1985, 1992). L: light; T: temperature; M: moisture; R: substrate reaction. The abbreviations of archeological areas are given in Table 1.

Temp: temperate; s.temp: south-temperate; temp-mont: temperate-montane; subkont: subcontinental; oc-med: oceanic-Mediterranean; oc-submed: oceanic-submediterranean; suboc-med: suboceanicMediterranean; suboc-submed: suboceanic-submediterranean; med: Mediterranean; submed: submediterranean; submed-oc: submediterranean-oceanic; submed-suboc: submediterranean-suboceanic; submed-suboc-mont: submediterranean-suboceanic-montane; submed-mont: submediterraneanmontane; med-oc: Mediterranean-oceanic; subbor: subboreal; subbor-mont: subboreal-montane; suboc: suboceanic.

\begin{tabular}{|c|c|c|c|c|c|c|c|c|c|c|c|c|}
\hline & \multicolumn{7}{|c|}{ Archaeological areas } & \multicolumn{4}{|c|}{ Ecological indicators } & \multirow[t]{2}{*}{ Chorotypes } \\
\hline Taxa & $\mathbf{C a}$ & En & Ia & Sg & SI & Si & So & $\mathbf{L}$ & $\mathbf{T}$ & $\mathbf{M}$ & $\mathbf{R}$ & \\
\hline Cephaloziella baumgartneri Schiffn. & $\bullet$ & $\mathrm{x}$ & - & - & - & $\mathrm{x}$ & $\mathrm{x}$ & 5 & 7 & 5 & - & oc-med \\
\hline Conocephalum conicum (L.) Dumort. & $\bullet$ & $\bullet$ & - & $\bullet$ & $\bullet$ & $\mathrm{x}$ & $\bullet$ & 7 & 3 & 7 & 7 & subbor-mont \\
\hline Fossombronia caespitiformis (Raddi) De Not. & $\bullet$ & $\bullet$ & $\bullet$ & $\mathrm{x}$ & $\mathrm{x}$ & $\mathrm{x}$ & $\mathrm{x}$ & 7 & 9 & 5 & 8 & oc-med \\
\hline Fossombronia pusilla $(\mathrm{L}$.$) Nees$ & $\bullet$ & - & $\bullet$ & $\bullet$ & $\bullet$ & $\mathrm{x}$ & $\bullet$ & 7 & 7 & 7 & 3 & suboc-submed \\
\hline Lunularia cruciata (L.) Dumort. ex Lindb. & $\mathrm{x}$ & $\bullet$ & $\bullet$ & $\bullet$ & $\mathrm{x}$ & $\mathrm{x}$ & - & 7 & 8 & 6 & 6 & oc-med \\
\hline Pellia endiviifolia (Dicks.) Dumort. & $\bullet$ & $\bullet$ & $\bullet$ & $\bullet$ & $\bullet$ & $\mathrm{x}$ & $\bullet$ & - & 4 & 8 & 9 & s.temp \\
\hline Riccia atromarginata Levier & $\bullet$ & $\bullet$ & $\bullet$ & $\bullet$ & $\bullet$ & • & $\mathrm{x}$ & - & • & • & $\bullet$ & med-oc \\
\hline Riccia glauca $\mathrm{L}$. & $\bullet$ & $\bullet$ & $\bullet$ & $\bullet$ & $\mathrm{x}$ & $\bullet$ & $\bullet$ & 8 & 5 & 7 & 5 & submed \\
\hline Riccia lamellosa Raddi & - & $\bullet$ & $\bullet$ & $\bullet$ & $\mathrm{x}$ & • & $\mathrm{x}$ & 8 & 9 & 5 & $\bullet$ & med \\
\hline Riccia sorocarpa Bisch. & $\bullet$ & - & $\bullet$ & - & $\mathrm{x}$ & $\bullet$ & - & 9 & $\bullet$ & 5 & 5 & temp \\
\hline Southbya tophacea (Spruce) Spruce & $\bullet$ & $\mathrm{x}$ & $\bullet$ & $\bullet$ & $\bullet$ & $\bullet$ & $\bullet$ & $\bullet$ & $\bullet$ & $\bullet$ & $\bullet$ & oc-med \\
\hline Sphaerocarpos michelii Bellardi & $\bullet$ & - & $\bullet$ & $\mathrm{x}$ & $\mathrm{x}$ & - & $\bullet$ & 7 & 8 & 6 & 6 & suboc-submed \\
\hline Targionia hypophylla $\mathrm{L}$. & $\bullet$ & $\bullet$ & $\bullet$ & $\bullet$ & $\mathrm{x}$ & $\bullet$ & $\bullet$ & 6 & 7 & 4 & 5 & oc-submed \\
\hline Aloina aloides (Koch ex Schultz) Kindb. & $\bullet$ & $\bullet$ & $\mathrm{x}$ & $\mathrm{x}$ & $\bullet$ & $\mathrm{x}$ & $\mathrm{x}$ & 7 & 6 & 4 & 9 & temp \\
\hline Aloina ambigua (Bruch \& Schimp.) Limpr. & $\bullet$ & $\bullet$ & $\bullet$ & $\bullet$ & $\mathrm{x}$ & $\mathrm{x}$ & $\mathrm{x}$ & 7 & 6 & 4 & 8 & submed \\
\hline Aloina rigida (Hedw.) Limpr & $\bullet$ & $\bullet$ & $\mathrm{x}$ & $\bullet$ & $\mathrm{x}$ & $\bullet$ & $\bullet$ & 7 & 4 & 5 & 6 & temp \\
\hline Barbula bolleana (Müll.Hal.) Broth. & $\bullet$ & $\bullet$ & $\bullet$ & $\bullet$ & $\bullet$ & $\mathrm{x}$ & $\bullet$ & 8 & 9 & 8 & 8 & submed \\
\hline Barbula convoluta Hedw. & $\bullet$ & $\bullet$ & $\mathrm{x}$ & - & $\mathrm{x}$ & $\mathrm{x}$ & $\mathrm{x}$ & 8 & $\bullet$ & 3 & 6 & temp \\
\hline Barbula unguiculata $\mathrm{Hedw}$. & $\mathrm{x}$ & $\bullet$ & $\mathrm{x}$ & $\mathrm{x}$ & $\mathrm{x}$ & $\mathrm{x}$ & $\mathrm{x}$ & 7 & $\bullet$ & 2 & 7 & temp \\
\hline Bryum argenteum Hedw. & $\bullet$ & $\bullet$ & $\mathrm{x}$ & $\bullet$ & $\mathrm{x}$ & $\mathrm{x}$ & $\mathrm{x}$ & 7 & • & 4 & 6 & temp \\
\hline Bryum canariense Brid. & $\mathrm{x}$ & $\bullet$ & $\bullet$ & $\mathrm{x}$ & $\bullet$ & $\bullet$ & $\bullet$ & $\bullet$ & $\bullet$ & $\bullet$ & $\bullet$ & submed \\
\hline Bryum dichotomum Hedw. & $\bullet$ & $\bullet$ & $\bullet$ & $\mathrm{x}$ & $\mathrm{x}$ & $\mathrm{x}$ & $\mathrm{x}$ & 8 & 6 & 6 & 5 & submed \\
\hline Bryum radiculosum Brid. & $\bullet$ & $\bullet$ & $\bullet$ & $\mathrm{x}$ & $\bullet$ & $\bullet$ & $\mathrm{x}$ & 9 & 6 & 2 & 7 & suboc-med \\
\hline Crossidium crassinervium (De Not.) Jur. & $\bullet$ & - & $\bullet$ & $\bullet$ & $\mathrm{x}$ & $\bullet$ & $\mathrm{x}$ & 9 & 8 & 2 & 8 & submed \\
\hline
\end{tabular}


Table 2. continued.

\begin{tabular}{|c|c|c|c|c|c|c|c|c|c|c|c|c|}
\hline Crossidium laxefilamentosum W.Frey \& Kürschner & $\bullet$ & $\bullet$ & $\bullet$ & $\bullet$ & $\bullet$ & $\bullet$ & $\mathrm{x}$ & $\bullet$ & $\bullet$ & $\bullet$ & $\bullet$ & $\bullet$ \\
\hline Crossidium squamiferum (Viv.)Jur. & $\bullet$ & $\bullet$ & $\bullet$ & $\bullet$ & $\mathrm{x}$ & $\bullet$ & $\mathrm{x}$ & 9 & 8 & $\mathrm{x}$ & 8 & submed \\
\hline Dicranella howei Renauld \& Cardot & $\bullet$ & $\bullet$ & $\bullet$ & $\mathrm{x}$ & $\mathrm{x}$ & $\bullet$ & $\bullet$ & 9 & 8 & 5 & 8 & oc-med \\
\hline Didymodon acutus (Brid.) K.Saito & $\bullet$ & $\bullet$ & $\mathrm{x}$ & $\bullet$ & $\mathrm{x}$ & $\mathrm{x}$ & $\mathrm{x}$ & 9 & 5 & - & 8 & submed \\
\hline Didymodon luridus Hornsch. & $\bullet$ & $\mathrm{x}$ & $\mathrm{x}$ & $\bullet$ & $\mathrm{x}$ & $\mathrm{x}$ & $\mathrm{x}$ & 9 & 6 & 2 & 8 & submed \\
\hline Didymodon rigidulus Hedw. & - & $\mathrm{x}$ & $\bullet$ & $\bullet$ & $\bullet$ & $\bullet$ & $\mathrm{x}$ & 5 & 3 & 4 & 7 & temp \\
\hline Didymodon tophaceus (Brid.) Lisa & $\bullet$ & $\mathrm{x}$ & $\mathrm{x}$ & $\bullet$ & $\bullet$ & $\bullet$ & - & 7 & - & 7 & 7 & temp \\
\hline $\begin{array}{l}\text { Didymodon tophaceus subsp. sicculus (M.J.Cano, } \\
\text { Ros, García-Zam. \& J.Guerra) Jan Kučera }\end{array}$ & - & - & $\bullet$ & $\mathrm{x}$ & $\bullet$ & $\bullet$ & $\mathrm{x}$ & - & - & - & - & med \\
\hline Didymodon vinealis (Brid.) R.H.Zander & $\mathrm{x}$ & & $\mathrm{x}$ & $\mathrm{x}$ & $\mathrm{x}$ & $\mathrm{x}$ & $\mathrm{x}$ & 9 & 6 & 2 & 7 & submed \\
\hline Entosthodon muhlenbergii (Turner) Fife & $\bullet$ & $\bullet$ & $\bullet$ & $\bullet$ & $\mathrm{x}$ & $\bullet$ & $\bullet$ & 9 & 6 & 5 & 8 & $\begin{array}{c}\text { submed-suboc- } \\
\text { mont }\end{array}$ \\
\hline Entosthodon pulchellus (H.Philib.) Brugués & $\bullet$ & $\bullet$ & - & $\mathrm{x}$ & $\mathrm{x}$ & - & - & 8 & 8 & 5 & 8 & submed-suboc \\
\hline Eucladium verticillatum (With.) Bruch \& Schimp. & & & & & & $\mathrm{x}$ & & 5 & 7 & 7 & 9 & submed \\
\hline Fissidens crassipes Wilson ex Bruch \& Schimp. & $\bullet$ & $\bullet$ & $\bullet$ & $\bullet$ & $\bullet$ & $\mathrm{x}$ & - & - & 6 & 8 & 8 & suboc-submed \\
\hline Fissidens gracilifolius Brugg.-Nann. \& Nyholm & $\bullet$ & $\bullet$ & $\bullet$ & $\bullet$ & $\bullet$ & $\mathrm{x}$ & $\bullet$ & 3 & 4 & 6 & 9 & temp-mont \\
\hline Fissidens pusillus (Wilson) Milde & - & $\bullet$ & $\bullet$ & - & $\mathrm{x}$ & $\bullet$ & - & 3 & 4 & 6 & 6 & temp-mont \\
\hline $\begin{array}{l}\text { Fissidens viridulus (Sw. ex anon.) Wahlenb var. } \\
\text { viridulus }\end{array}$ & $\bullet$ & $\bullet$ & $\bullet$ & $\bullet$ & $\mathrm{x}$ & $\mathrm{x}$ & $\mathrm{x}$ & 7 & 5 & 6 & 8 & submed \\
\hline Fontinalis antipyretica Hedw. & - & $\bullet$ & $\bullet$ & - & $\bullet$ & $\mathrm{x}$ & - & 8 & 5 & 9 & - & subbor \\
\hline Funaria hygrometrica Hedw. & $\bullet$ & $\bullet$ & $\mathrm{x}$ & $\mathrm{x}$ & $\mathrm{x}$ & $\bullet$ & $\bullet$ & 8 & - & 6 & 6 & temp \\
\hline Funariella curviseta (Schwägr.) Sérgio & - & $\bullet$ & - & $\mathrm{x}$ & $\mathrm{x}$ & $\bullet$ & $\bullet$ & 5 & 8 & 5 & 7 & med \\
\hline Gigaspermum mouretii Corb. & - & $\bullet$ & - & - & $\mathrm{x}$ & $\bullet$ & - & - & - & • & - & oc-med \\
\hline Grimmia crinita Brid. & - & $\mathrm{x}$ & $\bullet$ & - & $\bullet$ & $\bullet$ & - & 9 & 8 & - & 8 & submed \\
\hline Grimmia orbicularis Bruch ex Wilson & - & $\mathrm{x}$ & $\bullet$ & $\bullet$ & $\mathrm{x}$ & $\bullet$ & • & 9 & 7 & $\bullet$ & 8 & submed-mont \\
\hline Grimmia pulvinata (Hedw.) Sm & - & $\mathrm{x}$ & $\bullet$ & $\bullet$ & $\bullet$ & $\bullet$ & $\mathrm{x}$ & 9 & 5 & - & 7 & temp \\
\hline Gymnostomum calcareum Nees \& Hornsch. & - & $\mathrm{x}$ & $\mathrm{x}$ & - & $\bullet$ & $\mathrm{x}$ & - & 4 & 7 & 5 & 9 & submed-mont \\
\hline Gymnostomum viridulum Brid. & - & - & $\bullet$ & $\bullet$ & $\mathrm{x}$ & $\bullet$ & $\mathrm{x}$ & 4 & 8 & 4 & 9 & suboc-med \\
\hline Homalothecium aureum (Spruce) H.Rob. & - & - & $\bullet$ & $\bullet$ & $\mathrm{x}$ & $\bullet$ & - & 8 & 9 & 2 & 7 & med \\
\hline $\begin{array}{l}\text { Homalothecium lutescens (Hedw.) H.Rob. var. } \\
\text { lutescens }\end{array}$ & $\bullet$ & $\bullet$ & $\mathrm{x}$ & $\bullet$ & $\mathrm{x}$ & $\bullet$ & $\bullet$ & 9 & 4 & 2 & 8 & temp \\
\hline Homalothecium sericeum (Hedw.) Schimp. & $\bullet$ & $\mathrm{x}$ & $\bullet$ & - & - & $\mathrm{x}$ & - & 8 & 3 & 2 & 7 & temp \\
\hline $\begin{array}{l}\text { Hygroamblystegium varium (Hedw.) Mönk. var. } \\
\text { humile (P.Beauv.) }\end{array}$ & $\bullet$ & - & $\bullet$ & - & - & $\mathrm{x}$ & - & 5 & 5 & 6 & 4 & temp \\
\hline Kindbergia praelonga (Hedw.) Ochyra & & & & & & $\mathrm{x}$ & & 6 & 4 & 6 & 5 & temp \\
\hline Microbryum davallianum (Sm.) R.H.Zander & • & $\bullet$ & • & $\mathrm{x}$ & $\mathrm{x}$ & • & • & 8 & 5 & 6 & 6 & submed \\
\hline
\end{tabular}


Table 2. continued.

\begin{tabular}{|c|c|c|c|c|c|c|c|c|c|c|c|c|}
\hline Microbryum starckeanum (Hedw.) R.H.Zander & $\bullet$ & - & $\mathrm{x}$ & $\mathrm{x}$ & $\mathrm{x}$ & $\bullet$ & $\bullet$ & 9 & 6 & 7 & 5 & submed \\
\hline Orthotrichum diaphanum Schrad. ex Brid & - & - & - & - & $\mathrm{x}$ & - & - & 8 & 6 & 2 & 6 & temp \\
\hline Oxyrrhynchium speciosum Nees var. speciosum & $\bullet$ & - & $\bullet$ & $\bullet$ & $\bullet$ & $\mathrm{x}$ & $\bullet$ & 5 & 7 & 7 & 6 & subkont \\
\hline Pleuridium acuminatum Lindb. & - & - & - & - & - & $\mathrm{x}$ & $\bullet$ & 7 & 5 & 5 & 4 & suboc \\
\hline $\begin{array}{l}\text { Pohlia wahlenbergii (F.Weber \& D.Mohr) } \\
\text { A.L.Andrews var. wahlenbergii }\end{array}$ & - & $\mathrm{x}$ & $\bullet$ & $\bullet$ & $\mathrm{x}$ & $\bullet$ & $\bullet$ & 6 & - & 7 & 6 & subbor \\
\hline $\begin{array}{l}\text { Pseudocrossidium hornschuchianum (Schultz) } \\
\text { R.H.Zander }\end{array}$ & $\mathrm{x}$ & - & $\mathrm{x}$ & $\bullet$ & $\mathrm{x}$ & $\mathrm{x}$ & $\mathrm{x}$ & 9 & 5 & 2 & 7 & submed-suboc \\
\hline $\begin{array}{l}\text { Pseudocrossidium obtusulum (Lindb.) H.A.Crum \& } \\
\text { L.E.Anderson }\end{array}$ & - & - & $\bullet$ & - & $\bullet$ & $\bullet$ & $\mathrm{x}$ & - & - & - & - & - \\
\hline Pseudocrossidium replicatum (Taylor) R.H.Zander & $\bullet$ & $\bullet$ & $\bullet$ & $\bullet$ & - & - & $\mathrm{x}$ & 7 & 7 & 3 & 8 & temp \\
\hline Pseudocrossidium revolutum (Brid.) R.H.Zander & $\bullet$ & - & $\bullet$ & $\bullet$ & $\mathrm{x}$ & $\bullet$ & $\mathrm{x}$ & 7 & 6 & 3 & 8 & oc-submed \\
\hline $\begin{array}{l}\text { Ptychostomum capillare (Hedw.) Holyoak \& N. } \\
\text { Pedersen }\end{array}$ & - & $\mathrm{x}$ & $\mathrm{x}$ & - & $\mathrm{x}$ & $\mathrm{x}$ & - & 5 & - & 5 & 6 & temp \\
\hline $\begin{array}{l}\text { Ptychostomum imbricatulum (Müll.Hal.) Holyoak \& } \\
\text { N.Pedersen }\end{array}$ & $\mathrm{x}$ & & $\mathrm{x}$ & $\mathrm{x}$ & $\bullet$ & $\mathrm{x}$ & $\mathrm{x}$ & 8 & - & 5 & 6 & temp \\
\hline Rhynchostegiella littorea (De Not.) Limpr. & $\bullet$ & - & $\bullet$ & $\bullet$ & $\mathrm{x}$ & $\bullet$ & $\mathrm{x}$ & $4-$ & 5 & 5 & 8 & oc-med \\
\hline Rhynchostegiella tenella (Dicks.) Limpr. & $\bullet$ & $\bullet$ & $\bullet$ & $\bullet$ & $\mathrm{x}$ & $\bullet$ & $\bullet$ & 4 & 5 & 3 & 8 & submed-suboc \\
\hline Rhynchostegium riparioides (Hedw.) Cardot & $\bullet$ & $\bullet$ & $\bullet$ & $\bullet$ & $\bullet$ & $\mathrm{x}$ & $\bullet$ & $\bullet$ & 3 & 8 & 6 & temp \\
\hline Scleropodium touretii (Brid.) L.F.Koch. & - & - & $\bullet$ & $\bullet$ & - & $\mathrm{x}$ & - & 8 & 7 & 3 & 6 & oc-submed \\
\hline Scorpiurium circinatum (Bruch) M.Fleisch. \& Loeske & - & $\mathrm{x}$ & $\bullet$ & $\mathrm{x}$ & $\mathrm{x}$ & $\mathrm{x}$ & $\mathrm{x}$ & 6 & 7 & 3 & 5 & oc-med \\
\hline Syntrichia montana Nees & $\bullet$ & $\mathrm{x}$ & $\bullet$ & $\bullet$ & $\bullet$ & $\bullet$ & - & 9 & 6 & - & 8 & submed-mont \\
\hline Syntrichia ruralis (Hedw.) F.Weber \& D.Mohr & • & • & - & - & - & $\mathrm{x}$ & • & 9 & - & 2 & 6 & temp \\
\hline Timmiella anomala (Bruch \& Schimp.) Limpr. & $\mathrm{x}$ & $\bullet$ & - & - & - & $\mathrm{x}$ & - & 5 & 9 & 5 & 5 & med \\
\hline Timmiella barbuloides (Brid.) Mönk. & $\bullet$ & $\bullet$ & $\bullet$ & $\mathrm{x}$ & $\mathrm{x}$ & $\mathrm{x}$ & $\mathrm{x}$ & 5 & 9 & 5 & 8 & med \\
\hline Tortella flavovirens (Bruch) Broth. & $\bullet$ & $\bullet$ & $\bullet$ & $\bullet$ & $\mathrm{x}$ & $\bullet$ & $\bullet$ & 8 & 5 & 2 & 8 & suboc-submed \\
\hline Tortella inflexa (Bruch) Broth. & $\bullet$ & $\bullet$ & $\bullet$ & $\bullet$ & $\mathrm{x}$ & $\mathrm{x}$ & $\bullet$ & 4 & 8 & 3 & 9 & oc-med \\
\hline Tortella nitida (Lindb.) Broth. & $\bullet$ & $\bullet$ & $\mathrm{x}$ & - & $\mathrm{x}$ & $\mathrm{x}$ & $\mathrm{x}$ & 8 & 8 & 2 & 7 & oc-med \\
\hline Tortella squarrosa (Brid.) Limpr. & • & - & $\bullet$ & $\bullet$ & $\mathrm{x}$ & $\mathrm{x}$ & - & 9 & 8 & 2 & 6 & submed \\
\hline $\begin{array}{l}\text { Tortula acaulon (With.) R.H.Zander var. pilifera } \\
\text { (Hedw.) R.H.Zander }\end{array}$ & - & $\bullet$ & $\bullet$ & - & $\mathrm{x}$ & $\bullet$ & - & 9 & 6 & 2 & 7 & temp \\
\hline Tortula marginata (Bruch \& Schimp.) Spruce & $\bullet$ & $\bullet$ & $\bullet$ & $\mathrm{x}$ & $\mathrm{x}$ & $\mathrm{x}$ & $\bullet$ & 3 & 8 & 5 & 9 & oc-med \\
\hline Tortula muralis Hedw. & - & $\bullet$ & $\mathrm{x}$ & $\mathrm{x}$ & $\mathrm{x}$ & $\mathrm{x}$ & $\mathrm{x}$ & 8 & 5 & - & - & temp \\
\hline Tortula vahliana (Schultz) Mont & - & $\bullet$ & $\bullet$ & $\bullet$ & $\mathrm{x}$ & $\bullet$ & $\bullet$ & $\bullet$ & - & - & - & oc-med \\
\hline Trichostomum brachydontium Bruch & - & $\bullet$ & - & - & $\mathrm{x}$ & $\mathrm{x}$ & - & 8 & 6 & 2 & 8 & submed-mont \\
\hline
\end{tabular}


Table 2. continued.

\begin{tabular}{|c|c|c|c|c|c|c|c|c|c|c|c|c|}
\hline Trichostomum crispulum Bruch & $\bullet$ & $\bullet$ & $\bullet$ & $\bullet$ & $\mathrm{x}$ & $\mathrm{x}$ & $\bullet$ & 6 & 4 & 6 & 9 & temp \\
\hline Weissia condensa (Voit) Lindb. var. condensa & - & - & - & - & - & - & $\mathrm{x}$ & 9 & 7 & - & 9 & submed \\
\hline Weissia controversa Hedw. var. controversa & - & $\mathrm{x}$ & - & - & - & $\mathrm{x}$ & - & 7 & 4 & 4 & 6 & temp \\
\hline $\begin{array}{l}\text { Weissia controversa var. crispata (Nees \& Hornsch.) } \\
\text { Nyholm }\end{array}$ & - & - & - & - & - & - & $\mathrm{x}$ & 9 & 4 & $\bullet$ & 7 & submed-mont \\
\hline
\end{tabular}

As shown in Table 3, bryophyte species numerosity of the studied archaeological areas is very variable and does not exclusively depend on the size of the areas. The archaeological park of Selinunte, which is also by far the largest of those studied, hosts the highest number of bryophytes (51 taxa); however, in relation to the size of the areas the species richness of the Syracuse and Solunto parks is remarkable (38 and 33 taxa respectively).

From the chorological point of view, the floras are quite diversified since the Mediterranean taxa prevail in the floras of Selinunte (43.1\%), Segesta (50\%) and Solunto $(43,8 \%)$ parks and Catania site, while the temperate taxa are the most represented in Enna site (40\%) and in Mount Iato (55.6\%) and Syracuse parks (36.4\%) (Fig. 1). The high incidence of the latter type in the first two archaeological areas is likely to be related to their mountain altitudes, while in Syracuse park could be due to the significant presence of wet microhabitats in it.

An analysis of the average values of the Ellenberg index (Fig. 2) shows a relative uniformity of the floras with reference to the behaviour of the species with respect to the various factors, since the average values show variations of at most 1 and 1.5 units. Some significant differences may, however, be noted such as particularly high xerophily of the Solunto and Catania floras (average values of the moisture factor 3.7), the relatively low values concerning the temperature factor at the Enna site and in Mount Iato park (average value less than 6), the low value related to the reaction of the substrate in the area of Catania (6.3 average value).

A qualitative comparison of the floras, conducted through a cluster analysis, highlighted an accentuated diversification of the floras, as demonstrated by the low levels of link in the dendrogram of Fig. 3. Furthermore, it is observed that the clusters reflect the thermoclimatic conditions of the sites. The greatest similarity is found, in fact, among the floras of

Table 3. Number of bryophyte taxa in the archaeological areas. For abbreviations see Table 1.

\begin{tabular}{|l|c|c|c|c|c|c|c|}
\hline & Sl & Ia & Sg & Si & So & Ca & En \\
\hline Mosses & 44 & 18 & 18 & 36 & 28 & 6 & 13 \\
\hline Liverworts & 7 & 0 & 2 & 6 & 4 & 1 & 2 \\
\hline Total bryophyte taxa & 51 & 18 & 20 & 42 & 32 & 7 & 15 \\
\hline
\end{tabular}




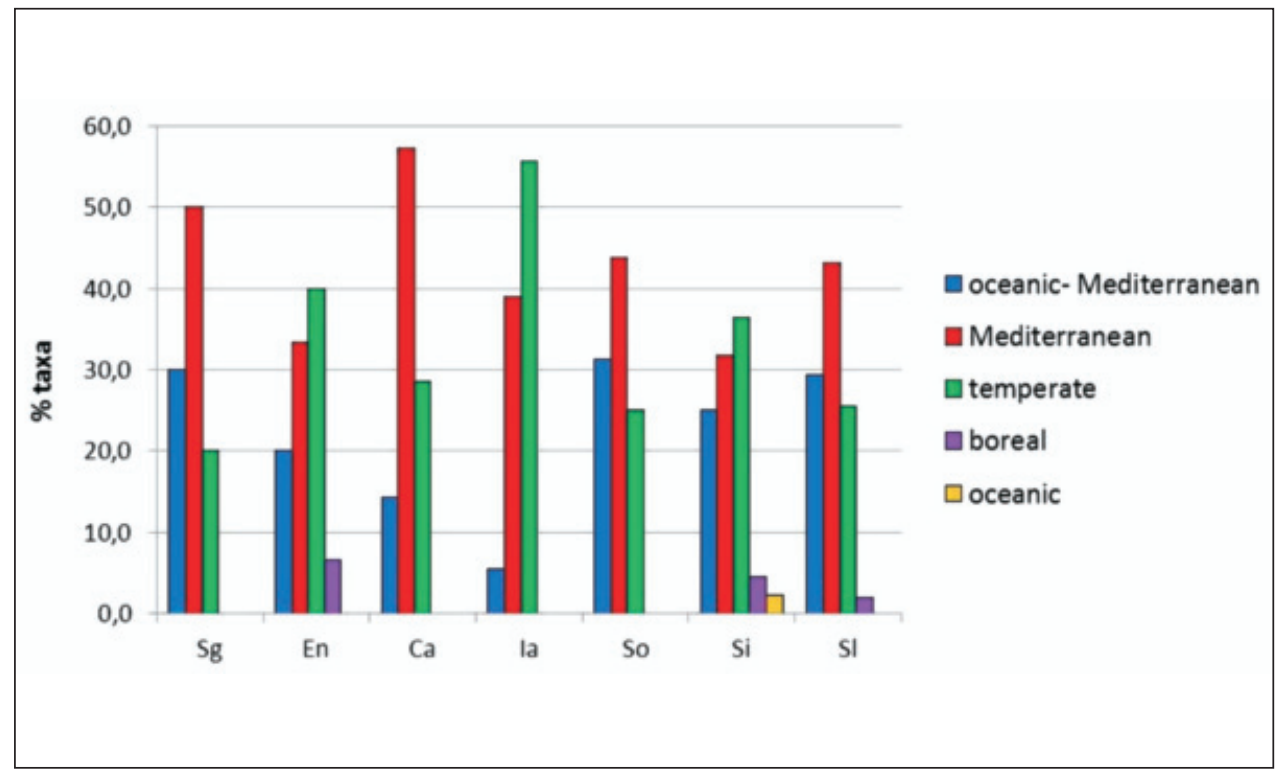

Fig. 1. Chorological Spectrum of bryofloras of studied areas. Chorological data are taken from Düll (1983, 1984, 1985, 1992). For abbreviations of archeological areas see Table 1.
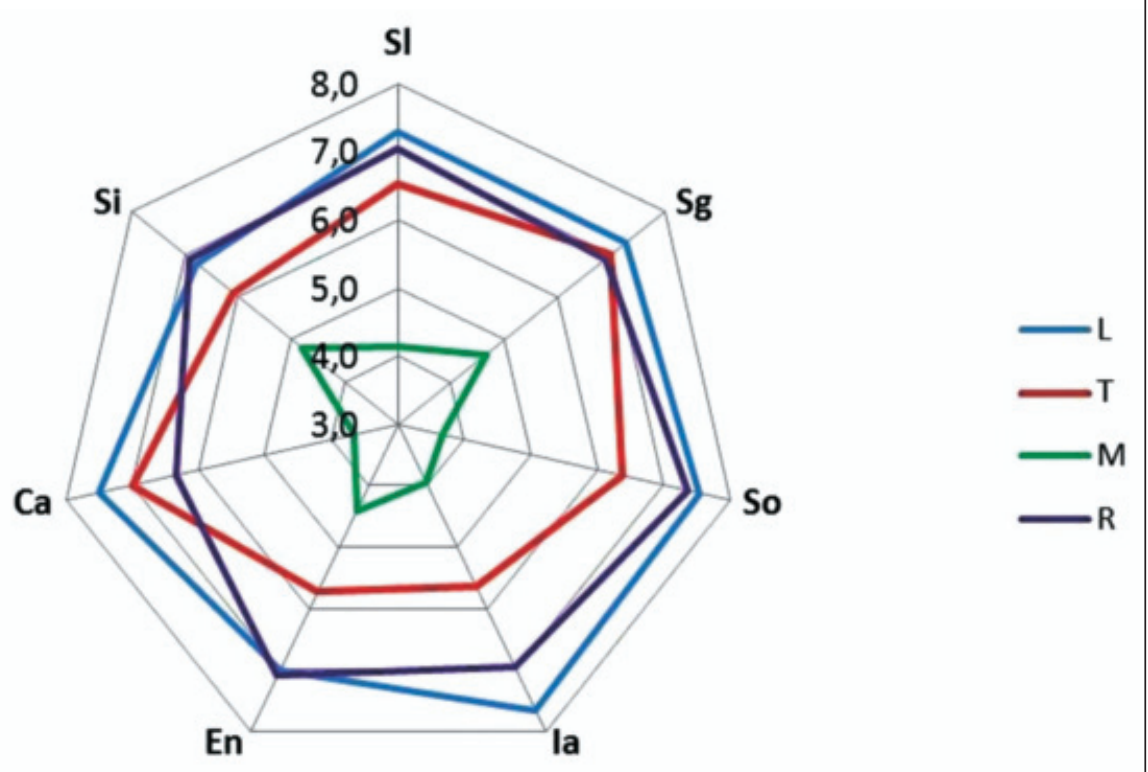

Fig. 2. Radar graph of average Ellenberg's indicator values (from Düll 1991) for taxa of studied bryofloras. The abbreviations of archeological areas are given in Table 1. 


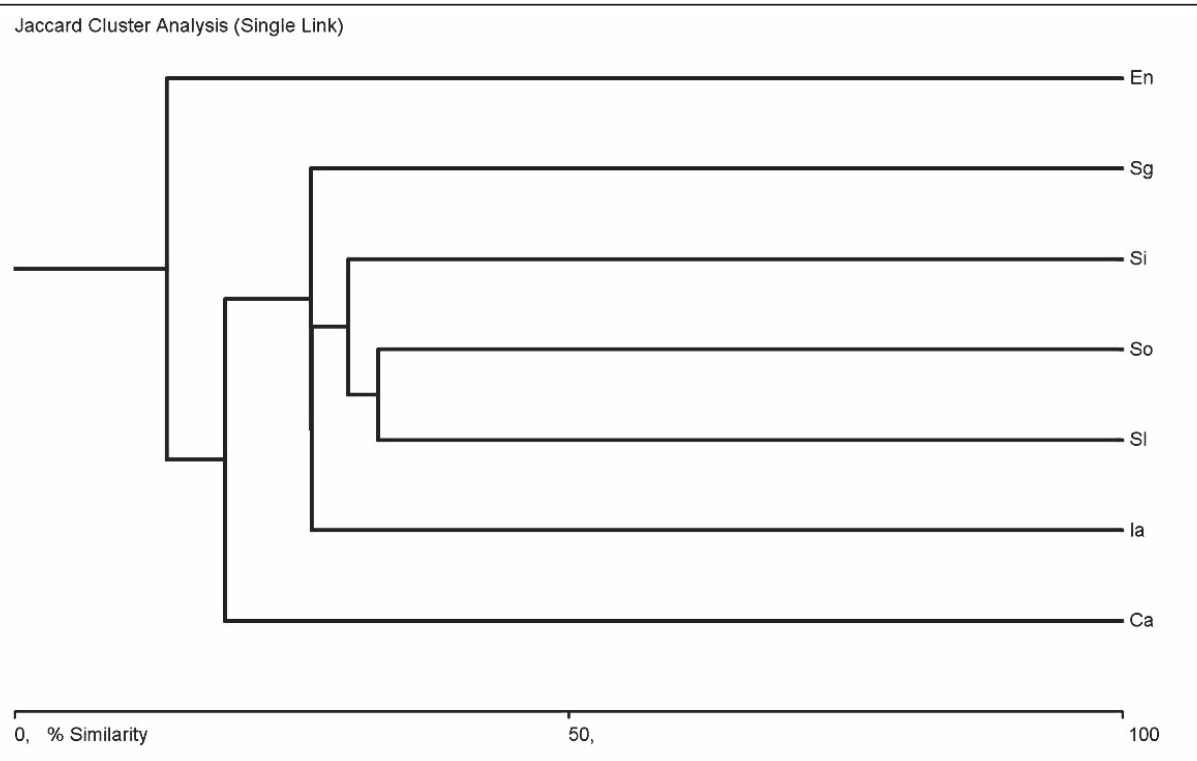

Fig. 3. Dendrogram of Jaccard's similarity (Jaccard 1908) among studied bryofloras.

Selinunte, Solunto and Syracuse, characterized by a lower thermomediterranean climate thermotype and to this cluster the floras of Mount Iato and Segesta (lower mesomediterranean climate thermotype), the flora of Catania (upper thermomediterranean climate thermotype) and, lastly, the one of Enna (upper mesomediterranean climate thermotype) are sequentially linked.

In addition to the high dissimilarity, the peculiarity of the floras of the Sicilian archaeological areas is due to the presence of taxa that be able to live almost exclusively in coastal areas with little disturbance. Among them four taxa, Crossidium laxefilamentosum W. Frey \& Kürschner, Gigaspermum mouretii Corb., Pseudocrossidium obtusulum (Lindb.) H.A. Crum \& L.E. Anderson and P. replicatum (Taylor) R. H. Zander., are of notable interest as they are very rare in Italy and candidates to inclusion in the European Red Data Book (Hodgetts 2015).

Pseudocrossidium replicatum was reported in Europe and Mediterranean basin only in Sicily (Solunto and Linosa) and Calabria (Dia \& al. 2003; Privitera \& Puglisi 2000; Ros $\&$ al. 2013; Hodgetts 2015). Elsewhere it is distributed in Central and South Africa, SouthWest Arabia and America (Zander 1981; Menzel 1986; Frey \& Kürschner 1988a 1988b). In the archeological park of Solunto it lives on basic soil in interstices between quartz mosaic tesserae of the houses floors.

Pseudocrossidium obtusulum was reported from North America Europe, Asia and Africa, (Fedosov \& Ignatova 2006; Khalil \& Farag Abu-Elhamd Ali 2018). It is very rare in the Mediterranean basin, where it is only known from Andorra, Egypt, Sicily, Spain and Turkey (Ros \& al. 2013; Khalil \& Farag Abu-Elhamd Ali 2018). In Sicily, it was only recorded in Solunto and Linosa (Dia \& Campisi 2006; Privitera \& Puglisi 2009). At Solunto it lives togeth- 
er with Pseudocrossidium replicatum in interstices between quartz mosaic tesserae of the houses floors in the archaeological park.

Gigaspermum mouretii is an oceanic-Mediterranean species scattered in Syria, Israel, Cyprus, Turkey, Crete, Sicily, Morocco, Canary Islands, Spain, and Balearic Islands (Ros $\&$ al. 2013). In Italy it was reported only from two locality of Sicily (Selinunte and Capaci) (Campisi \& al. 2008). At Selinunte it grows on calcarenite plinth of the temples E and F.

Crossidium laxefilamentosum was reported from Europe, Asia (Arabian peninsula) and Africa. In the Mediterranean basin it is known from Egypt, Serbia, Sicily, Tunisia and Turkey (Ros \& al. 2013). In Sicily it was recorded only in two archaeological areas (Solunto and Molino a Vento near Gela) (Dia \& Campisi 2009; Puglisi \& al. 2013). At Solunto it lives on exposed soil among ruins of the archaeological park.

On the basis of coverage, frequency, abundance of sporophytes and propagules data as well as the life strategies of taxa living in the Segesta, Selinunte and Solunto archaeological parks, some species of mosses were identified as a potentially great threat to the state of conservation of the ruins in consideration of the direct correlation between species diffusion and coverage on the one hand and their possible biodeteriogenic action on the other. In particular, they are Tortula muralis Hedw., Scorpiurium circinatum (Bruch) M. Fleisch. \& Loeske and Didymodon vinealis (Brid.) R. H. Zander, which are present in all three areas, always reaching cover class II or higher. Furthermore, Aloina ambigua (Bruch \& Schimp.) Limpr., Barbula convoluta Hedw., Bryum dichotomum Hedw., Didymodon luridus Hornsch., Funariella curviseta (Schwägr.) Sérgio, Pseudocrossidium hornschuchianum (Schultz) R. H. Zander and Tortella nitida (Lindb.) Broth. occure in at least 2 areas with high frequency or coverage class (III or more) at least in one area. All these species, with the exception of the pleurocarp moss Scorpiurium circinatum, are annual or colonists, biological strategies that according to Dierßen (2001) are characterized by short-lived $(<1$ year-few years) with more or less high reproductive effort. They present a high production of sporophytes already in the first year of growth or after 2-3 years or form also propagules in the first years of life and, therefore, tend to expand more and more on the stone substrates, continuously creating new colonies. On the contrary, the perennial species Scorpiurium circinatum, shows reproductive effort low and begin to form sporophytes only after several years. It forms very wide moss mats that extend above all on horizontal surfaces of archaeological structures in the studied areas.

The liverworts also show a high reproductive capacity both through the sporification and with different modality of vegetative propagation (propagules production in Lunularia cruciata (L.) Lindb. and y-shaped growth form in Riccia species). Five out of seven species (Fossombronia caespitiformis De Not. ex Rabenh., Riccia glauca L., $R$. lamellosa Raddi, $R$. sorocarpa Bisch., and Sphaerocarpos michelii Bellardi) present an "annual" strategy, being characterized by a very rapid growth of the vegetative body (few months) and very high formation of spores (Dierßen 2001). However, these species spread more widely on soils and, therefore, do not reach high frequency values on the ruins, where, except for Fossombronia caespitiformis, they have a low degree of coverage due to their small size.

Regarding the periods of maximum sporification, it is observed that most bryophytes release the spores in the spring (Table 4). In some cases the maturation of the sporophytes is a little early and occurs already in later winter (February and March), in others it is pro- 
Table 4. Frequency and cover classes, sporophyte or propagule presence, time of sporophyte production and life strategies (from Dierßen 2001) of taxa growing in the sites of Segesta (Sg), Selinunte (Sl) and Solunto (So). a: annual; c: colonist; ec: ephemeral colonist; 1: long-lived shuttle p: perennial; pc: competitive perennial; s: short-lived shuttle; sp: stress tolerant perennial. For abbreviations of archeological areas see Table 1 .

\begin{tabular}{|c|c|c|c|c|c|c|c|c|c|c|c|}
\hline Taxa & \multicolumn{3}{|c|}{$\begin{array}{c}\text { Frequency } \\
\text { classes }\end{array}$} & \multicolumn{3}{|c|}{ Cover classes } & \multicolumn{3}{|c|}{$\begin{array}{l}\text { Sporophyte or } \\
\text { propagule }\end{array}$} & \multirow[t]{3}{*}{ Sporification period } & \multirow[t]{2}{*}{$\begin{array}{c}\text { Life } \\
\text { strategies }\end{array}$} \\
\hline & $\mathrm{Sg}$ & & So & $\mathrm{Sg}$ & $\mathrm{Sl}$ & So & $\mathrm{Sg}$ & $\mathrm{Sl}$ & So & & \\
\hline Hepaticae & & & & & & & & & & & \\
\hline Cephaloziella baumgartneri & $\bullet$ & $\bullet$ & $\mathrm{I}$ & $\bullet$ & $\bullet$ & I & $\bullet$ & $\bullet$ & + & Late winter-early & $\mathrm{c}$ \\
\hline Fossombronia caespitiformis & I & II & I & IV & II & II-III & + & + & + & Winter & $\mathrm{a}$ \\
\hline Lunularia cruciata & $\bullet$ & I & $\bullet$ & $\bullet$ & $\mathrm{I}$ & $\bullet$ & $\bullet$ & + & $\bullet$ & $\bullet$ & $\mathrm{p}$ \\
\hline Riccia atromarginata & $\bullet$ & $\bullet$ & I & $\bullet$ & $\bullet$ & II & - & $\bullet$ & - & Late winter-early & $\mathrm{a}$ \\
\hline Riccia glauca & $\bullet$ & I & $\bullet$ & $\bullet$ & I & $\bullet$ & - & + & - & Late winter-early & $\mathrm{a}$ \\
\hline Riccia lamellosa & $\bullet$ & I & $\mathrm{I}$ & $\bullet$ & I & II & - & + & + & Late winter-early & $\mathrm{a}$ \\
\hline Riccia sorocarpa & $\bullet$ & I & $\bullet$ & $\bullet$ & I & $\bullet$ & - & + & - & Late winter-early & $\mathrm{a}, \mathrm{s}$ \\
\hline Sphaerocarpos michelii & I & I & $\bullet$ & I & I & $\bullet$ & + & + & - & Late winter-early & $\mathrm{a}$ \\
\hline Targionia hypophylla & $\bullet$ & I & $\bullet$ & $\bullet$ & I & $\bullet$ & + & + & + & Spring-summer & 1 \\
\hline Musci & & & & & & & & & & & \\
\hline Aloina aloides & I & $\bullet$ & I & I & $\bullet$ & I & - & $\bullet$ & $\bullet$ & Winter-spring & $\mathrm{c}$ \\
\hline Aloina ambigua & $\bullet$ & III & I & $\bullet$ & III & I & $\bullet$ & + & - & Winter-spring & $\mathrm{c}$ \\
\hline Aloina rigida & $\bullet$ & I & $\bullet$ & $\bullet$ & I & $\bullet$ & $\bullet$ & $\bullet$ & $\bullet$ & Winter-spring & $\mathrm{c}$ \\
\hline Barbula convoluta & $\bullet$ & III & I & $\bullet$ & I & I & $\bullet$ & $\bullet$ & - & $\bullet$ & $\mathrm{c}$ \\
\hline Barbula unguiculata & I & I & I & I & I & I & $\bullet$ & $\bullet$ & $\bullet$ & Spring & $\bullet$ \\
\hline Bryum argenteum & $\bullet$ & I & I & $\bullet$ & I & I & $\bullet$ & $\bullet$ & + & Winter-spring & $\mathrm{c}$ \\
\hline Bryum canariense & I & $\bullet$ & $\bullet$ & II & $\bullet$ & $\bullet$ & $\bullet$ & $\bullet$ & $\bullet$ & $\bullet$ & \\
\hline Bryum dichotomum & I & III & I & II & III & I & $\bullet$ & + & + & Spring & $\mathrm{cp}$ \\
\hline Bryum radiculosum & I & $\bullet$ & I & II & $\bullet$ & I & + & $\bullet$ & + & $\bullet$ & ce \\
\hline Crossidium crassinerve & $\bullet$ & I & I & $\bullet$ & I & II & $\bullet$ & $\bullet$ & + & Spring & $\mathrm{c}$ \\
\hline Crossidium laxefilamentosum & $\bullet$ & $\bullet$ & I & $\bullet$ & $\bullet$ & I & $\bullet$ & $\bullet$ & $\bullet$ & $\bullet$ & $\mathrm{c}$ \\
\hline Crossidium squamiferum & $\bullet$ & I & I & $\bullet$ & I & I & $\bullet$ & $\bullet$ & + & Spring & $\mathrm{c}$ \\
\hline Dicranella howei & I & II & $\bullet$ & I & I & $\bullet$ & $\bullet$ & $\bullet$ & $\bullet$ & Winter-spring & $\mathrm{c}$ \\
\hline Didymodon acutus & $\bullet$ & I & II & $\bullet$ & I & I-II & $\bullet$ & $\bullet$ & $\bullet$ & Spring & $\mathrm{c}$ \\
\hline Didymodon luridus & $\bullet$ & IV & II & $\bullet$ & III & I-II & $\bullet$ & $\bullet$ & $\bullet$ & Spring & $\mathrm{c}$ \\
\hline Didymodon rigidulus & $\bullet$ & $\bullet$ & I & $\bullet$ & $\bullet$ & I & $\bullet$ & $\bullet$ & + & $\bullet$ & $\mathrm{c}$ \\
\hline $\begin{array}{l}\text { Didymodon tophaceous } \\
\text { subsp. sicculus }\end{array}$ & II & $\bullet$ & $\mathrm{I}$ & II & $\bullet$ & I & $\bullet$ & $\bullet$ & $\bullet$ & $\bullet$ & $\mathrm{c}$ \\
\hline Didymodon tophaceus & $\bullet$ & $\mathrm{I}$ & $\bullet$ & $\bullet$ & $\mathrm{I}$ & $\bullet$ & $\bullet$ & $\bullet$ & $\bullet$ & Spring & $\bullet$ \\
\hline Didymodon vinealis & II & III & II & I-II & III & I-II & $\bullet$ & $\bullet$ & $\bullet$ & Spring-summer & $\mathrm{c}$ \\
\hline Entosthodon muhlenbergiii & $\bullet$ & I & $\bullet$ & $\bullet$ & I & $\bullet$ & $\bullet$ & $\bullet$ & $\bullet$ & Spring & $\mathrm{a}$ \\
\hline Entosthodon pulchellus & I & I & $\bullet$ & I & I & $\bullet$ & + & + & $\bullet$ & Spring & $\mathrm{a}$ \\
\hline Fissidens viridulus & $\bullet$ & I & $\mathrm{I}$ & $\bullet$ & I & II & $\bullet$ & $\bullet$ & + & Spring-summer & ec \\
\hline Funaria hygrometrica & I & I & $\bullet$ & I & II & $\bullet$ & + & + & $\bullet$ & Spring-summer & $\mathrm{f}$ \\
\hline Funariella curviseta & III & I & $\bullet$ & I-IV & II & $\bullet$ & + & + & $\bullet$ & Spring & $\mathrm{a}$ \\
\hline Gigaspermum mouretii & $\bullet$ & I & $\bullet$ & $\bullet$ & I & $\bullet$ & $\bullet$ & $\bullet$ & $\bullet$ & Autumn & $\mathrm{c}$ \\
\hline Grimmia orbicularis & $\bullet$ & I & $\bullet$ & $\bullet$ & I & $\bullet$ & $\bullet$ & + & $\bullet$ & Spring & $\mathrm{c}$ \\
\hline Grimmia pulvinata & $\bullet$ & $\bullet$ & I & $\bullet$ & $\bullet$ & $\mathrm{I}$ & $\bullet$ & $\bullet$ & + & Winter-spring & $\mathrm{c}$ \\
\hline Gymnostomum viridulum & $\bullet$ & II & $\mathrm{I}$ & $\bullet$ & II & II & $\bullet$ & $\bullet$ & + & Spring-summer & $\mathrm{c}$ \\
\hline Homalothecium aureum & $\bullet$ & I & $\bullet$ & $\bullet$ & I & $\bullet$ & $\bullet$ & $\bullet$ & $\bullet$ & Spring & $\mathrm{p}$ \\
\hline Homalothecium lutescens & $\bullet$ & I & $\bullet$ & $\bullet$ & I & $\bullet$ & $\bullet$ & $\bullet$ & $\bullet$ & Spring & $\mathrm{p}$ \\
\hline Microbryum davallianum & II & I & $\bullet$ & I & I & $\bullet$ & + & + & $\bullet$ & Winter-spring & $\mathrm{a}$ \\
\hline Microbryum starckeanum & I & I & $\bullet$ & I & I & $\bullet$ & + & + & $\bullet$ & Winter-spring & a \\
\hline Orthotrichum diaphanum & $\bullet$ & I & $\bullet$ & $\bullet$ & I & $\bullet$ & $\bullet$ & + & $\bullet$ & Spring & $\mathrm{c}$ \\
\hline Pohlia wahlenbergii & $\bullet$ & I & $\bullet$ & $\bullet$ & I & $\bullet$ & $\bullet$ & $\bullet$ & $\bullet$ & Spring-summer & $\mathrm{pc}$ \\
\hline Pseudocrossidium & $\bullet$ & II & I & $\bullet$ & III & I & $\bullet$ & $\bullet$ & $\bullet$ & Spring & $\mathrm{c}$ \\
\hline Pseudocrossidium replicatum & $\bullet$ & $\bullet$ & II & $\bullet$ & $\bullet$ & II & $\bullet$ & $\bullet$ & $\bullet$ & $\bullet$ & $\mathrm{c}$ \\
\hline Pseudocrossidium revolutum & $\bullet$ & I & II & $\bullet$ & II & $\mathrm{I}$ & $\bullet$ & $\bullet$ & + & Spring & $\mathrm{c}$ \\
\hline Ptychostomum capillare & $\bullet$ & II & $\bullet$ & $\bullet$ & I & $\bullet$ & $\bullet$ & & $\bullet$ & Spring-summer & $\mathrm{c}$ \\
\hline Ptychostomum imbricatulum & II & $\bullet$ & I & I-II & $\bullet$ & II & $\bullet$ & $\bullet$ & $\bullet$ & Spring-summer & $\mathrm{c}$ \\
\hline Rhynchostegiella littorea & $\bullet$ & I & I & $\bullet$ & I & I & $\bullet$ & $\bullet$ & $\bullet$ & Spring & $\mathrm{sp}$ \\
\hline Rhynchostegiella tenella & $\bullet$ & I & $\bullet$ & $\bullet$ & I & $\bullet$ & $\bullet$ & $\bullet$ & $\bullet$ & Autumn & $\mathrm{sp}$ \\
\hline Scorpiurium circinatum & I & III & I & $\mathrm{V}$ & $\mathrm{V}$ & II-V & $\bullet$ & $\bullet$ & $\bullet$ & Spring & $\mathrm{p}$ \\
\hline Timmiella barbuloides & I & I & I & V & II & III & + & $\bullet$ & $\bullet$ & Spring-summer & $\mathrm{s}$ \\
\hline Tortella flavovirens & $\bullet$ & I & $\bullet$ & $\bullet$ & I & $\bullet$ & $\bullet$ & $\bullet$ & $\bullet$ & Spring & $\mathrm{c}$ \\
\hline Tortella inflexa & $\bullet$ & I & $\bullet$ & $\bullet$ & I & $\bullet$ & $\bullet$ & $\bullet$ & $\bullet$ & Spring & $\mathrm{c}$ \\
\hline Tortella nitida & $\bullet$ & IV & III & $\bullet$ & $\mathrm{V}$ & II-V & $\bullet$ & + & + & Autumn & $\mathrm{sp}$ \\
\hline Tortella squarrosa & $\bullet$ & $\mathrm{I}$ & $\bullet$ & $\bullet$ & I & $\bullet$ & $\bullet$ & $\bullet$ & $\bullet$ & Spring & $\mathrm{pc}$ \\
\hline
\end{tabular}


Table 4. continued.

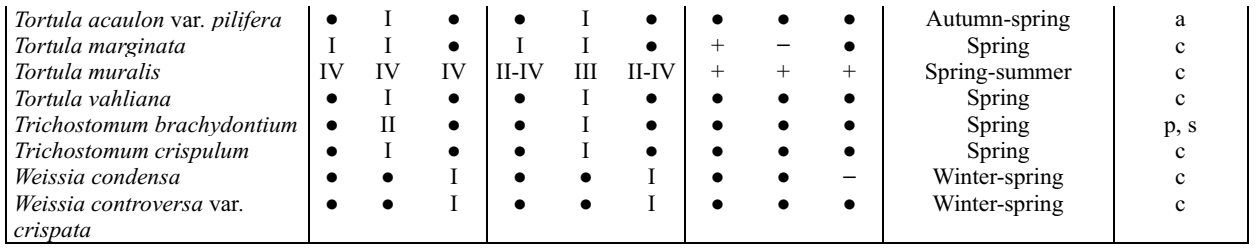

longed in the summer. Few species have autumnal sporification. Therefore, the analysis of these data suggests that the winter is the most suitable season to guarantee the effectiveness of the interventions on the ruins.

\section{Conclusive considerations}

Overall, this analysis confirms the naturalistic interest of archaeological areas for their significant floristic diversity and species richness, whose values are comparable to those recorded in Sicily in some natural areas (Campisi \& al. 2006). The importance of these areas is also increased by the presence of some rare taxa in Europe for which specific attention would be required during the necessary, periodic, restorative interventions on remains of architectural structures.

These cleaning interventions should primarily be aimed at the removal of widespread bryophytes with numerous or extensive colonies, considering that the action of biodeterioration is certainly related to the degree of bryophyte coverage. Furthermore, the possibility of diffusion of spores and propaguls due to colony detachment operations should not be underestimated.

Nevertheless, it should be emphasized that further research is desirable to better clarify the biodeteriogenic role of different bryophyte taxa, so far ascertained only in some epilithic moss species (Hughes 1982; Altieri \& Ricci 1994; Altieri \& al. 1997). Many species on lithic structures, indeed, are not true saxicolous but they settle only in small accumulations of soil in grooves and fractures caused by the alteration usually due to other deteriogenic agents; hence, the possibility that they, like other terricolous bryophytes, can exercise, instead, a protective action on substrates cannot be excluded with certainty at least in some cases. The important role of moss coverings against soil erosion is, in fact, well known both in forest ecosystems and in arid habitats where they contribute to the formation of the biological soil crusts, very effective to counteract the action of atmospheric agents (Weber \& al. 2016).

\section{Acknowledgements}

The authors thank the anonymous reviewers for their helpful suggestions. Support by Selinunte and Cave di Cusa Archeological Park is gratefully acknowledged. 


\section{References}

Aiello P., Dia M. G. \& Provenzano F. 2003: Flora briofitica e biodeterioramento dei siti archeologici siciliani: le briofite insediate sulle rovine di Segesta e Solunto. - Quad. Bot. Amb. Appl. 14: 187-197.

Altieri, A. \& Ricci, S. 1994: Il ruolo delle briofite nel biodeterioramento dei materiali lapidei. - Pp. 329-334 in: La conservazione dei monumenti nel bacino del Mediterraneo, Atti $3^{\circ}$ Symp. Intern. (Venezia 22-25 giugno 1994).

—, Coladonato, M., Lonati, G., Malagodi, M., Nugari, M. P. \& Salvadori, O. 1997: Effects of biocidal treatments on some italian lithotypes samples. - Pp: 31-40 in: A. Moropoulou, A., Zezza, E., Kollias, E., Papachristodoul, I. (eds) Proceedings IV International symposium on the conservation of monuments in the Mediterranean Basin. - Athens.

Campisi, P., Dia, M. G. \& Aiello, P. 2006: Analisi preliminare della diversità briofitica nei principali habitat della Sicilia. - Inform. Bot. Ital. 38: 139-144.

—, Lo Re, M. G. \& Dia, M. G. 2008: Gigaspermum mouretii Corb. - Inform. Bot. Ital. 40: 137-138.

— \& Provenzano, F. 2004: New record in Sicily of Gigaspermum mouretii (Gigaspermaceae, Musci), rare species in Europe. - Fl. Medit. 14: 305-308.

Celesti-Grapow, L., Pignatti, S. \& Pignatti, W. E. 1993-1994: Analisi della flora dei siti archeologici di Roma. - Allionia 32: 113-118.

Ceschin, S., Caneva, G. \& Kumbaric, A. 2006: Biodiversità ed emergenze floristiche nelle aree archeologiche romane. - Webbia 61(1): 133-144. https://doi.org/10.1080/ 00837792.2006 .10670797$.

Di Benedetto, L. \& Grillo, M. 1998: Contributo alla conoscenza dei biodeteriogeni rilevati nel complesso archeologico del Teatro greco-romano ed Anfiteatro romano di Catania. - Quad. Bot. Amb. Appl. 6(1995): 61-66.

Dia, M. G. \& Campisi, P. 2006: First record of Pseudocrossidium obtusulum (Lindb.) H.A. Crum L.E. Anderson (Pottiaceae, Musci) in Italy. - Nova Hedwigia 82(1-2): 205-208. https://doi.org/10.1127/0029-5035/2006/0082-0205

— \& - 2009: New or interesting records to the moss flora of Italy. - Cryptog. Bryol. 30(1): 199-201.

-, Privitera, M. \& Puglisi, M. 2003: New reports of Pseudocrossidium replicatum (Pottiaceae, Musci) from Sicily. - Fl. Medit. 13: 297-301.

Dierßen, K. 2001: Distribution, ecological amplitude and phytosociological characterization of european bryophytes. - Bryophytorum Biblioth. 56: 1-289.

Domina, G. 2018: The floristic research in Italian archaeological sites. - Fl. Medit. 28: 377-383. https://doi.org/10.7320/FlMedit28.377

Düll, R. 1983: Distribution of the European and Macaronesian liverworts (Hepaticophytina). Bryol. Beitr. 2: 1-114.

- 1984: Distribution of the European and Macaronesian mosses (Bryophytina). Part I - Bryol. Beitr. 4: 1-113.

- 1985: Distribution of the European and Macaronesian mosses (Bryophytina). Part II - Bryol. Beitr. 5: 110-232.

- 1991: Valori degli indicatori ecologici per muschi ed epatiche. - Pp. 69-91 in: Mastracci, M. (ed.), Congresso internazionale di Briologia. L'Aquila 15-26 luglio 1991. Atti del Convegno. L'Aquila.

- 1992: Distribution of the European and Macaronesian mosses (Bryophytina). Annotations and Progress. - Bryol. Beitr. 8/9: 1-223.

Fedosov, V. E. \& Ignatova, E. A. 2006: The genus Pseudocrossidium R.S. Williams (Pottiaceae, Musci) in Russia. - Arctoa 15: 203-210. https://doi.org/10.15298/arctoa.15.09

Frey, W. \& Kürschner, H. 1988a: Bryophytes of the Arabian Peninsula and Socotra. Floristics, phyto- 
geography and definition of the Xerothermic Pangean element. Studies in Arabian bryophytes 12. - Nova Hedwigia 46: 37-120.

— \& - 1988b: Pseudocrossidium replicatum (Tayl.) Zander replaces Barbula acutata C. Muell A note on its synonymy, distribution and the xeropottioid life syndrome. - Cryptog. Bryol. Lichenol. 9(2): 95-102.

Grella, L., Arduini, C. \& Uboldi, L. 1997: I beni archeologici in Italia. - Milano.

Gueli, L., Lo Giudice, R., Dia, M. G., \& Campisi, P. 2005: Biodeteriogeni vegetali (Tracheofite, Briofite) in siti archeologici e complessi monumentali della Sicilia. - Infor. Bot. Ital. 37(A): 82-83.

Guglielmo, A., Privitera, M., Puglisi, M. \& Prezzavento, A. D. 2003: Brioflora e grado di urbanizzazione nella città di Siracusa (Sicilia sud-orientale). - Quad. Bot. Amb. Appl. 14: 211-219.

Hodgetts, N. G. 2015: Checklist and country status of European bryophytes - towards a new Red List for Europe. Irish Wildlife Manuals, 84. - Dublin.

Hughes, J. G. 1982: Penetration by rhizoids of the moss Tortula muralis into well cemented oolitic limestone. - Intern. Biodeterioration Bull. 18(2): 43-46.

Jaccard, P. 1908: Nouvelles recherches sur la distribution florale. - Bull. Soc. Vaud. Sci. Nat. 44: 223-270.

Khalil, M. I. \& Farag Abu-Elhamd Ali, M. 2018: Additional Pottiaceae Records from Omayed Protected Area, Egypt. - Egypt. J. Exp. Biol. (Bot.) 14(2): 339-345. https://doi.org/10.5455/egyjebb.20181116035159

Kučera, J. Blockeel,T. L., Erzberger, P., Papp, B., Soldán, Z., Vellak, K., Werner, O., Ros, R. M. 2018: The Didymodon tophaceus Complex (Pottiaceae, Bryophyta) Revisited: New Data Support the Subspecific Rank of Currently Recognized Species. - Cryptog. Bryol. 39(2): 241257. https://doi.org/10.7872/cryb/v39.iss2.2018.241

Lo Giudice, R. \& Cristaudo, A. 1998: Biodeteriogeni vegetali dei complessi monumentali e archeologici della città di Enna (Sicilia centrale). - Quad. Bot. Amb. Appl. 6(1995): 167-180.

Lucchese, F. \& Pignatti Wikus, E. 1995: Il verde nelle aree archeologiche. - Pp. 80-90 in: Cignini, B., Massari, G. \& Pignatti, S. (eds), L'Ecosistema Roma, ambiente e territorio. - Roma.

McAleece, N, Lambshead, P, Paterson, G, \& Gage, J. 1997: Bio-diversity professional V2.0. - Oban. Menzel, M. 1986: Beitrag zur andinen Laubmoosflora von Peru. - Willdenowia 15: 529-555.

Minissale, P. Trigilia, A., Brogna, F. \& Sciandrello, S. 2015: Plants and Vegetation in the Archaeological Park of Neapolis of Syracuse (Sicily, Italy): A Management Effort and also an Opportunity for Better Enjoyment of the Site. - Conserv. Manag. Archaeol. Sites 17(4): 340369. https://doi.org/10.1080/13505033.2016.1175906.

Pesaresi, S., Galdenzi, D., Biondi E. \& Casavecchia, S. 2014: Bioclimate of Italy: application of the worldwide bioclimatic classification system- - J. Maps 10(4): 538-553. https://doi.org/10.1080/17445647.2014. 891472.

Privitera, M. \& Puglisi, M. 2000: A new record for the European moss flora: Pseudocrossidum replicatum (Tayl.) Zander (Pottiaceae, Musci). - Nova Hedwigia 70(3): 479-484.

— \& - 2009: The circum-Sicilian islands as important refuge areas for some remarkable bryophytes. - Pl. Biosyst. 143(S1): 126-135.

— \& Scelsi, F. 1996: La flora briofitica del Castello di Eurialo e delle Mura Dionigiane di Siracusa (Sicilia). - Pp 567-576 in: Piccione, V. \& Antonelli, C. (eds) Atti IV Workshop Progetto Strategico C.N.R. "Clima, Ambiente e Territorio nel Mezzogiorno". - Lecce.

Puglisi, M. 1999: Bryophyte vegetation on the archaeological sites of Syracuse (SE Sicily). - Arch. Geobot. 3(2): 201-211.

-, Campisi, P., Dia, M. G. \& Privitera, M. 2013: Additional reports for Italian moss flora. - Pl. Biosyst. 147(2): 525-528. https://doi.org/10.1080/11263504.2013.806365 
Raimondo, F. M., Aiello, P., Campisi, P., Geraci, A., Mannino, A. M. \& Merlo, F. 1998: Contributo alla conoscenza dei biodeteriogeni dei materiali lapidei in ambito urbano. - Quad. Bot. Amb. Appl. 6(1995): 143-159.

Ros, R. M., Mazimpaka, V., Abou-Salama, U., Aleffi, M., Blockeel, T. L., Brugués, M., Cros, R. M., Dia, M. G., Dirkse, G. M., Draper, I., El-Saadawi, W., Erdağ, A., Ganeva, A., Gabriel, R., González-Mancebo, J., Granger, C., Herrnstadt, I., Hugonnot, V., Khalil, K., Kürschner, H., Losada-Lima, A., Luís, L., Mifsud, S., Privitera, M., Puglisi, M., Sabovljević, M., Sérgio, C., Shabbara, H. M., Sim-Sim, M., Sotiaux, A., Tacchi, R., Vanderpoorten, A., Werner, O. 2013: Mosses of the Mediterranean, an annotated checklist. - Cryptog. Bryol. 34: 99-283. https://doi.org/10.7872/cryb.v34.iss2.2013.99

Söderström, L., Hagborg, A., von Konrat M., BartholomewBegan, S., Bel,1 D., Briscoe, L., Brown, E., Cargil,1 D. C., Costa, D. P., Crandall-Stotler, B. J., Cooper, E. D., Dauphin, G., Engel, J. J., Feldberg, K., Glenny, D., Gradstein, S. R., He, X., Heinrichs, J., Hentschel, J., Ilkiu-Borges, A. L., Katagiri, T., Konstantinova, N. A., Larraín, J., Long, D. G., Nebel, M., Pócs, T., Felisa Puche, F., Reiner-Drehwald, E, Renner, M. A. M., Sass-Gyarmati, A., Schäfer-Verwimp, A., Moragues, J. G. S., Stotler, R. E., Sukkharak, P., Thiers, B. M., Uribe, J., Váňa, J., Villarreal, J. C., Wigginton, M., Zhang, L., Zhu, R.-L. 2015: World checklist of hornworts and liverworts. - PhytoKeys 59: 1-828. https://doi.org/10.3897/phytokeys.59.6261

Weber, B., Büdel, B. \& Belnap, J. (eds) 2016: Biological soil crusts: an organizing principle in drylands,. - Basel. https://doi.org/10.1007/978-3-319-30214-0_1

Zander, R. H. 1981: Descriptions and illustrations of Barbula, Pseudocrossidium and Bryoerythrophyllum (P.P.) of Mexico. - Cryptog. Bryol. 1: 1-22.

Addresses of the authors:

Patrizia Campisi ${ }^{1 *}$, Maria Giovanna Dia ${ }^{1} \&$ Mattia Letizia Marino ${ }^{2}$,

${ }^{1}$ Department of Biological, Chemical and Pharmaceutical Science and Technology, University of Palermo, via Archirafi, 38, 90123 Palermo - Italy. E-mail: patrizia.campisi@unipa.it; m.giovanna.dia@unipa.it;

${ }^{2}$ via dei Cedri n. 4091100 Trapani - Italy. E-mail: mattialetizia.marino@gmail.com *corresponding author. 
